\title{
Two steps forward, One Step back
}

\section{Case Comment: One Step (Support) Ltd v Morris- Garner and another}

Author: $\quad$ Caspar Bartscherer*

Keywords: $\quad$ Contract, Remedies, Damages, Wrotham Park

Abstract: $\quad$ One Step is an important decision that deals with the circumstances in which a claimant may recover damages in contract on the so-called Wrotham Park basis, valued as the amount that would hypothetically have been negotiated between willing parties to release the defendant from his obligation. This note argues that although the Supreme Court was right not to award damages on this basis in this case, the test laid down by their Lordships for when such damages are available is unclear and will be difficult to apply.

Word Count: 4229

Word Count (including footnotes): $\quad 4944$ ${ }^{*}$ Faculty of Laws, University College London. I am grateful to Charles Mitchell, Harrison Tait, Aaron Taylor and
the anonymous referee for their comments on earlier drafts of this note. All errors, naturally, remain my own. 
In One Step v Morris-Garner, ${ }^{1}$ the Supreme Court recently had an opportunity to consider awards of damages on the so-called Wrotham Park basis. The proceedings before the Supreme Court had attracted some academic interest in advance because of the potentially drastic impact of the decision of the Court of Appeal $^{2}$ which appeared to have significantly widened the category of cases in which these types of damages were available. They are known as Wrotham Park damages after the case of that name, ${ }^{3}$ in which Brightman $\mathrm{J}$ awarded damages on this basis for the first time, but as Lord Reed suggests in One Step, it is perhaps best to call them negotiating damages to avoid confusion.

The facts of One Step were fairly unremarkable in themselves. The defendants were in the business of providing support services to young adults leaving local authority care; these services were provided to several local authorities. The claimant company was incorporated in 2002 to enable a Mr and Mrs Costelloe to take a half share in the business. Mrs Costelloe and the first defendant each owned 50 per cent of the issued share capital in the claimant and $\mathrm{Mr}$ Costelloe and the second defendant were employed in leading positions by the claimant. The relationship between the defendants and the Costelloes subsequently deteriorated, and, in 2006, Mrs Costelloe triggered a deadlock notice, requiring the first defendant to choose between either buying Mrs Costelloe’s shares in the claimant for the sum of $£ 3.15 \mathrm{~m}$ or selling her shares to Mrs Costelloe for that amount. The first defendant opted for the latter option.

The sale agreement included a provision obligating both defendants not to use the claimant's confidential information in any subsequent business ventures as well as a provision prohibiting

\footnotetext{
${ }^{1}$ One Step (Support) Ltd v Morris-Garner and another [2018] UKSC 20, [2018] 2 WLR 1353.

${ }^{2}$ One Step (Support) Ltd v Morris-Garner and another [2016] EWCA Civ 180, [2017] QB 1; Paul Davies wrote about the decision of the Court of Appeal in Lloyd's Maritime and Commercial Law Quarterly, Paul S Davies, 'One Step Forwards: The Availability of Wrotham Park Damages for Breach of Contract One Step v MorrisGarner' [2017] Lloyd's Maritime and Commercial Law Quarterly 201.

${ }^{3}$ Wrotham Park Estate Co Ltd v Parkside Homes Ltd [1974] 1 WLR 798.
} 
them, for a period of three years, from competing with the claimant in the provision of certain services within a specified area. In 2007, the defendants, in breach of the sale agreement, started competing using confidential information they had obtained surreptitiously before the sale. In 2008, solicitors for the claimants wrote to the defendants threatening to bring proceedings to obtain an injunction, but, in the event, nothing came of it. Whilst the claimant's business floundered, the defendants' new business flourished. In 2010, shortly after their obligation not to compete had expired, the defendants sold their new business for some $£ 12.8 \mathrm{~m}$.

Proceedings were issued in 2012. In 2014, Phillips J trying a preliminary matter at first instance, held that the claimant was entitled to elect between ordinary compensatory damages and negotiating damages. ${ }^{4}$ The Court of Appeal unanimously upheld this decision. While the concurring judgment of Longmore LJ attempted to lay down more structured criteria for determining when negotiating damages would be available in breach of contract claims, Christopher Clarke LJ, with whose judgment King LJ agreed, merely stated that the question for the court was "what remedy is required to avoid injustice[.]" In light of this broad potential availability of negotiating damages, the leading judgment of Lord Reed restricting the availability of these damages is to be welcomed.

The Supreme Court unanimously allowed the defendants' appeal, ordering a hearing on the quantum of damages which were to be calculated on the conventional basis. However, as Lord Carnwarth observed in his concurring judgment, there were "significant differences" between Lord Reed's leading judgment, given with the concurrence of Lady Hale, Lord Wilson and

\footnotetext{
${ }^{4}$ One Step (Support) Ltd v Morris-Garner and another [2014] EWHC 2213 (QB), [2015] IRLR 215;

${ }^{5}$ One Step (Support) Ltd v Morris-Garner and another (n 2) [[120]].
} 
Lord Carnwarth, and the minority reasoning of Lord Sumption. ${ }^{6}$ This should be of little practical significance, since, as Lord Reed somewhat obliquely asserts, his Lordship's judgment clearly "represents the view of a majority of the court[.]"7

After a brief survey of the facts, Lord Reed's judgment reviews the fundamental principles underpinning awards of damages in tort, contract, and for infringements of property rights and intellectual property rights. Building on the distinction, drawn by Lord Shaw in Watson, Laidlaw, ${ }^{8}$ between restoration to the position $\mathrm{C}$ would have been in had D performed, and compensation on a "user principle" calculated on the basis of "price or hire", ${ }^{9}$ his Lordship makes it clear that only the former is available in ordinary cases of breach of contract. ${ }^{10}$ Lord Reed shows this to be uncontroversial with references to a number of cases including Robinson $v$ Harman $^{11}$ and the Supreme Court's recent decision in Bunge. ${ }^{12}$ In this vein, Lord Reed reprises the point made by Lord Sumption in Bunge ${ }^{13}$ that "damages for breach of contract are based on the difference to the claimant between the outcome of performance and nonperformance", and not, importantly, on valuing the right infringed itself. ${ }^{14}$ Quite independently of whether there are inherent reasons why a legal system should choose to offer a remedy based on one or the other basis of valuation for the infringement of contractual rights, it is indubitably the case that adopting the same approach across the board greatly enhances a legal system's adherence to the rule of law values of consistency and predictability.

\footnotetext{
${ }^{6}$ One Step (n 1) [127].

7 ibid [101].

${ }^{8}$ Watson, Laidlaw \& Co Ltd v Pott, Cassels and Williamson 1914 SC (HL) 18.

${ }^{9}$ One Step (n 1) [27].

${ }^{10}$ One Step (Support) Ltd v Morris-Garner and another [2018] UKSC 20, [2018] 2 WLR 1353 [95(6)].

${ }^{11}$ Robinson v Harman (1848) 1 Exch 850.

${ }^{12}$ One Step (n 1) [32]; Bunge SA v Nidera BV (formerly Nidera Handelscompagnie BV) [2015] UKSC 43, [2015]

3 All ER 1082.

${ }^{13}$ Bunge SA v Nidera BV (formerly Nidera Handelscompagnie BV) (n 12) [[21]].

${ }^{14}$ One Step (n 1) [76].
} 
By contrast to ordinary contractual damages, valuing the difference between performance and breach, "an award based on a hypothetical release fee depends on considering the outcome if the contract had not been performed but had been replaced by a different contract." 15 Thus, his Lordship holds that except in "certain circumstances[,]"16 negotiating damages are unavailable for breach of contract. Rather, negotiating damages are available for those invasions of property rights and similar interests - namely, intellectual property, and rights of confidentiality - that are calculated on a user basis, and compensate $\mathrm{C}$ for the infringement of their "valuable right to control" the use of the physical asset or intellectual property in question. ${ }^{17}$ Notably, Lord Reed explains Wrotham Park itself on this basis, since the Wrotham Park Estate was suing for the enforcement of a restrictive covenant - an equitable proprietary right. ${ }^{18}$ Damages awarded under Lord Cairns' Act $^{19}$ are similarly explained on a quasiproprietary basis. Since "the refusal of an injunction had the effect of depriving the claimant of an asset which had an economic value[,]" the award of negotiating damages in lieu is compensation for the loss of the asset value of the injunction. ${ }^{20}$

Marking a clear division between property-based, and similar, claims where negotiating damages are available and contract-based claims where they are not has the distinct advantage of being consistent with recent authority on the correct conceptualization of damages for breach of contract. ${ }^{21}$ However, this appearance of clarity is unfortunately not supported by the

\footnotetext{
15 ibid [91].

16 ibid.

17 ibid [54], [76]; or, as Lord reed puts it at [66]: "[D] prevents [C] from exercising his right to obtain the economic value of the use in question, and should therefore compensate him for that loss."

18 ibid [53]-[54].

${ }^{19}$ Originally contained in s.2 of the Chancery Amendment Act 1858 (Lord Cairns' Act), the power to award damages in lieu of an injunction is now contained in s.50 of the Senior Courts Act 1981.

${ }^{20}$ ibid [63].

${ }^{21}$ Most notably the emphasis on valuing performance rather than the contractual right as an article of commerce in Bunge SA v Nidera BV (formerly Nidera Handelscompagnie BV) (n 12) that was discussed above; cf also the approach of the majority in Golden Strait Corp v Nippon Yusen Kubishika Kaisha (The Golden Victory) [2007] UKHL 12; [2007] 2 AC 353.
} 
judgment, since Lord Reed introduces further instances in which negotiating damages are available that do not fit this neat two-fold dichotomy. Thus, his Lordship suggested that the award of negotiating damages can be explained on the basis of D's infringement of C's valuable right to control the use made by D of an economic opportunity - Pell Frischmann ${ }^{22}$ and Vercoe $v$ Rutland Fund Management ${ }^{23}$ - or D's intellectual property ${ }^{24}$ - Experience Hendrix. ${ }^{25}$ His Lordship also suggests that negotiating damages are available in any instance in which D's breach results in $\mathrm{C}$ similarly losing a valuable asset. ${ }^{26}$ Acknowledging that any contractual right might be defined as an asset, his Lordship adds that "what is important is that the contractual right is of such a kind that its breach can result in an identifiable loss equivalent to the economic value of the right, considered as an asset, even in the absence of any pecuniary losses which are measurable in the ordinary way."27

What unites the examples Lord Reed uses to illustrate this category [93] - "a right to control the use of land, intellectual property or confidential information" - is that although performance might not have any economic value to $\mathrm{C}$, her contractual right to control D's behaviour is nonetheless valuable to her and she might be able to extract economic value from that right, rather than from performance. What this category correctly recognises is that contractual rights have economic value that is distinct from the economic value of the performance of the underlying obligation. Given that $\mathrm{C}$ can always agree to release $\mathrm{D}$ from his obligations, and that she is free to demand economic compensation for that release, any

\footnotetext{
${ }^{22}$ Pell Frischmann Engineering Ltd v Bow Valley Iran Ltd and others [2009] UKPC 45, [2011] 1 WLR 2370.

${ }^{23}$ Vercoe and others v Rutland Fund Management Ltd and others [2010] EWHC 424 (Ch).

${ }^{24}$ One Step (n 1) [84]-[91].

${ }^{25}$ Experience Hendrix LLC v PPX Enterprises Inc and another [2003] EWCA Civ 323, [2003] 1 All ER (Comm) 830.

${ }^{26}$ One Step (n 1) [91]-[92].

27 ibid [93].
} 
contractual right gives $\mathrm{C}$ a bargaining chip which is economically valuable independent of the economic value of performance to $\mathrm{C}$.

Attempting to shape our theory of when negotiating damages are available in order to accommodate this realisation raises the problem that it is unclear how we should distinguish between contracts where performance creates the economic value for $\mathrm{C}$ and those where the existence of her right creates the economic value. The idea that the bundle of rights that makes up, say, a freehold in land or other 'ownership' interest includes an enforceable right to control the use of that land ${ }^{28}$ as well as a right to extract economic value from that right to control is uncontentious. However, the fact that in practice $\mathrm{C}$ can similarly extract economic value from many contractual rights in virtue of her ability to release D from his obligations for consideration does not provide an argument for the law protecting this incidental benefit of C's contractual rights. It is unclear how Lord Reed foresees extending a quasi-proprietary right to extract economic value to some contractual rights while simultaneously withholding it from others without proffering any concrete criteria to draw the line between them.

It is similarly unclear what the difference between Experience Hendrix, Pell Frischmann and Vercoe, on the one hand, and One Step, on the other hand, is that makes it the case that $\mathrm{C}$ had a right to 'control use' in the former but not on the facts of the latter. In fact, much unifies these cases: $\mathrm{C}$ had a contractual right that $\mathrm{D}$ not engage in a specified activity; $\mathrm{C}$ could have obtained an injunction to restrain D from doing that activity, but did not do so; and, $\mathrm{C}$ then brought a claim, post-breach, to obtain damages for the breach of that negative obligation. Due to the availability of specific relief, all of these cases involved $\mathrm{C}$ having the ability to control (through

\footnotetext{
${ }^{28}$ Penner, for instance, views a right to control as indispensable to both enjoyment and alienability, two of the most commonly cited key features of full 'ownership'; James E Penner, 'The Bundle of Rights Picture of Property' (1995) 43 UCLA L.Rev. 711, 745-747.
} 
the threat of an injunction) what $\mathrm{D}$ did prior to $\mathrm{D}$ doing so. As a sidenote, although it might be suggested that Pell Frischmann and Vercoe can be categorised as based on C's right to confidence, the claim in both of those cases included but was not exclusively based on such a right to confidential information. Furthermore, the claimant in One Step also had a right to confidence and yet no negotiating damages were awarded. In any event, Experience Hendrix would remain a pure case of contractual rights considered as an asset.

Apart from the difficulty of distinguishing these cases from One Step itself and thus the difficulty of determining whether future contractual rights are quasi-proprietary in this way or not, there is a certain level of circularity involved in the reasoning. To wit, the only reason the courts could have found that $\mathrm{C}$ had a right to control use, rather than a simple right to performance of D's negative obligation, is that $\mathrm{C}$ had a right that $\mathrm{D}$ not do an act and that performance of that right was specifically enforceable ex ante. That specific enforcement, however, was based just on a simple contractual right to performance; its availability cannot be prayed in aid to infer that $\mathrm{C}$ has rights that are greater than the right that the relief was based on in the first place - ie rights to control use. Of course, it is true that in these situations, we can describe C's contractual right, coupled with the availability of specific relief, as a right to control use ex ante any threatened breach; it is also true that - as a consequence of a) the fact that $\mathrm{D}$ might wish to get out of that obligation and might be willing to pay to do so combined with b) the parties' freedom to create a new contract varying that obligation - that right is a valuable asset. However, until the courts choose to protect that asset ex post breach, there is nothing that necessarily makes this a valuable asset once $\mathrm{C}$ has failed to obtain an injunction and D has breached his obligation. 
It is a cold fact about our legal system that not everything that was once valuable to claimants is legally protected at all times. Thus, if $\mathrm{C}$ operates the only shop in a small town, she has a valuable asset in the future custom of the towns inhabitants. That right enjoys some legal protections, such as a right to be free from D physically preventing customers from visiting the shop. However, C has no right to restrain D from opening another shop in the same town and thus reducing the value of her asset. C's asset is protected by the law in one way, but that protection does not make it the case, absent further positive reasons, that the law must protect it in any other ways. C's contractual right to D's performance is, in some ways, akin to C's liberty to operate her shop: it is a valuable asset in that it advances C's economic interests, and the law protects her interests from certain interferences, but not from others. Moreover, we could also imagine $\mathrm{C}$ extracting some economic value from her liberty to operate her shop, in a manner similar to her ability to extract economic value from her contractual rights. As a consequence of the parties' freedom to create a contract varying their obligations, $\mathrm{C}$ could extract economic value from her liberty by, for instance, granting D a license to prevent customers from entering her shop if D was willing to pay for that license.

Unfortunately, the circular reasoning that forms the basis upon which a contractual right can be elevated to the quasi-proprietary status that justifies negotiating damages is a feature the judgments in One Step share with earlier judgments. Thus, in Pell Frischmann, Lord Walker seems to have justified the award of substantial negotiating damages on the basis of C's negative "veto right" to prevent D from entering into the proposed oil exploration agreement. ${ }^{29}$ The fact that at the time the claim in that case was brought an injunction would no longer be available was, as in One Step, no obstacle to the award of substantial negotiating damages.

\footnotetext{
${ }^{29}$ Pell Frischmann (n 22).
} 
After this confusion surrounding contractual rights as valuable assets, it might have been hoped that Lord Sumption's judgment could clarify matters. Regrettably, however, that hope must be dashed. Disposing of the appeal in One Step, his Lordship agrees with the majority that the courts below were wrong to offer an election of negotiating damages but goes on to suggest that the hypothetical bargain measure of those damages could nonetheless be relevant to estimating loss on its ordinary conceptualization. ${ }^{30}$ His Lordship's categorisation of the cases in which negotiating damages have thus far been awarded also differs markedly from Lord Reed's. In a passage that bears setting out in full, his Lordship suggests a tripartite classification of:

"(i) cases in which damages are not limited to pecuniary loss, because the claimant has an interest in the observance of his rights which extends beyond financial reparation; (ii) cases in which the claimant would be entitled to the specific enforcement of his right, and the notional release fee is the price of non-enforcement; and (iii) cases in which the claimant has suffered (or may be assumed to have suffered) pecuniary loss, and the notional release fee is treated as evidence of that loss." ${ }^{31}[109]$

The least need be said about Category (ii). It seems to be largely coterminous with Lord Reed's negotiating damages awarded under Lord Cairns' Act, although, unlike Lord Reed, Lord Sumption sees Wrotham Park itself as a case of this kind, classifying it as essentially a contract claim. ${ }^{32}$ Category (i) covers invasions of property rights and is to that extent also similar to Lord Reed's characterization of the circumstances in which negotiating damages are available.

\footnotetext{
${ }^{30}$ One Step (n 1) [106].

31 ibid 109.

32 ibid [112], [114].
} 
However, it is both under-inclusive and over-inclusive of the majority categorisation. It is under-inclusive of that categorization since it relegates intellectual property rights to Category (iii), for which negotiating damages are only available as evidence of loss. It is over-inclusive since it extends to Blake. ${ }^{33}$ That case is included because, in his Lordship's estimation, the Attorney General had a "non-pecuniary governmental interest" in the defendant keeping state secrets. ${ }^{34}$ This demarcation of the category - by reference to the question of whether $\mathrm{C}$ has a non-pecuniary interest in performance - would appear to be vulnerable to the same criticism of indeterminacy as Lord Reed's 'valuable asset' test.

The most problematic category, however, is Category (iii). While not a category where negotiating damages are available per se, his Lordship suggests a hypothetical bargain could nonetheless be a helpful proxy for the value of performance - and hence loss - since they are how the parties, reasonably, would have valued that performance. ${ }^{35}$ It should be added at this juncture that Lord Reed had also seen some scope for a hypothetical bargain to be helpful in estimating loss, but thought that courts should only do so where there had in fact been negotiations between the parties. It is thus unlikely that any of Lord Sumption's categorisation will be applied by the courts below.

Nonetheless, Lord Sumption's categorisation raises issues that are of general academic interest. His Lordship's paradigm case for this category are user damages for patent infringement. Patent cases, his Lordship reasons, are not proprietary in the same way that trespass is, since the patentholder does not have more than a pecuniary interest in D keeping his obligation. ${ }^{36}$ Having used Lord Halsbury LC's famous example of sitting on a chair which its owner never

\footnotetext{
${ }^{33}$ Attorney General v Blake [2000] UKHL 45, [2001] 1 AC 268.

${ }^{34}$ One Step (n 1).

35 ibid [115].

36 ibid [116], [119].
} 
uses to explain the non-pecuniary interest underpinning the availability of negotiating damages in his category (i),${ }^{37}$ Lord Sumption asserts that, by way of contrast, due to the very nature of a patent, this is not so where D makes a patented article. Whereas the owner of a chair has a non-pecuniary interest in non-interference with his chair, the patent-holder only has a pecuniary interest in exploiting his patent. ${ }^{38}$ Thus, negotiating damages do not value the infringement of a right to control use, but are, rather, a proxy for the value of performance - ie a proxy for the losses $\mathrm{C}$ has sustained from diverted sales. ${ }^{39}$ Further, in his Lordship's scheme, this category also explains Experience Hendrix, Pell Frischmann, and Vercoe, as well as One Step itself, since a release fee can be seen as the value reasonable people would have put on D's performance. ${ }^{40}$

The explanation of Experience Hendrix, Pell Frischmann, Vercoe, and One Step on this basis can be welcomed with some caution, since at least this categorisation does not attempt to draw an unsupportable distinction between the former cases and One Step. However, unfortunately, that is where the advantages of this category end. First, as Lord Carnwarth politely points out in his judgment, this explanation of patents, whatever its merits may be, upends over one hundred years of precedent on the availability of negotiating damages as of right for the infringement of patents. ${ }^{41}$ As Lord Carnwarth notes, the courts in the patent cases in which negotiating damages were available have been abundantly clear that the availability of such

\footnotetext{
37 ibid [110]; compare The Owners of the Steamship "Mediana" v The Owners, Master and Crew of the Lightship "Comet", The "Mediana" [1900] AC 113 at 117 per Earl of Halsbury LC.

${ }^{38}$ One Step (n 1) [119].

39 ibid.

${ }^{40}$ Pell Frischmann, Vercoe [121]; Experience Hendrix [122]; as to One Step, Lord Sumption would order the court below "neither to require nor to exclude the use of a notional release fee as evidence of the claimant's loss", [124]; One Step (n 1).

41 ibid [132]-[135].
} 
damages is " "not confined to the physical use of another's property" and can be justified by “"analogy” with conversion[.]"42

Secondly, the merits of this explanation are also questionable. Lord Sumption's explanation does not seems to make a distinction between cases of diverted sales and cases where the patent-holder is not producing the patented product in the market in which the defendant operates. Thus, in Watson, Laidlaw, the House of Lords awarded user damages despite the pursuer not operating in the market in which the defender had produced the offending articles, with Lord Shaw explicitly drawing the analogy with full proprietary rights by using the example of a horse that stands idly in its stables and whose owner would nonetheless be entitled to user damages if it were taken out for a ride. ${ }^{43}$ Although it might be objected that even where the $\mathrm{C}$ does not operate in the same market as $\mathrm{D}$ she will have lost revenue she could have made from licensing the product to $\mathrm{D}$ or his competitors, that objection only works where $\mathrm{C}$ is willing to license the product in that market. Where $\mathrm{C}$ is neither operating in the market nor in the habit of giving licenses in that market, she has simply not suffered any financial loss. Consequently, there is no loss that negotiating damages could be a proxy for. Yet, courts have habitually awarded negotiating damages for the infringement of the patentholder's right in cases of this kind; therefore, negotiating damages in cases of patent infringement cannot be conceptualised as a proxy for loss in the manner envisaged by Lord Sumption.

\footnotetext{
42 ibid [135]; citing Fletcher Moulton LJ in Stoke- on-Trent City Council $v$ W \& J Wass Ltd [1988] 1 WLR 1406 at 1416H and Lord Denning MR in Seager v Copydex Ltd (No 2) [1969] 1 WLR 809 at 813, respectively.

${ }^{43}$ Lord Sumption explicitly references Lord Halsbury LC's example of sitting on a chair that is never used by its owner in describing the non-pecuniary interest available in his Category (i); ibid [110]; compare The Mediana (n 37).
} 
Thirdly, even if negotiating damages could be conceptualised as a proxy for the loss $\mathrm{C}$ has suffered, it would seem to be a bad proxy for that loss, unless the losses C and D would have reasonably expected $\mathrm{C}$ to make and the gains $\mathrm{C}$ and $\mathrm{D}$ would have reasonably expected $\mathrm{D}$ to make are similar and also correspond to the loss $\mathrm{C}$ actually has made. There is some evidence that this unlikely assumption underpins Lord Sumption's judgment since his Lordship asserts that $\mathrm{C}$ would have no reason to extract more than she anticipates losing from D's competition and $\mathrm{D}$ has no reason to pay more than that sum. ${ }^{44}$ That assumption is unreasonable for several reasons. To begin, as the facts of Pell Frischmann illustrate, the parties' ex ante assumptions can often be wildly different from profits actually realized and losses actually incurred. It is no answer to say that the parties can be hypothetically constructed to have accurate foresight, since the accuracy of their foresight can only be determined if the court already has a rough idea of the region in which C's loss - calculated on the ordinary basis - lies, in which case there would be no need to construct a proxy for that loss. However, even making the highly unlikely supposition that the actual parties have reasonably accurate foresight, ${ }^{45} \mathrm{C}$ might well be in a position to extract more than the profit she would anticipate to make. Take the following example, of a defendant who is more apt at extracting profit from the situation that the claimant: Suppose that C could expect to lose $£ 100$ from D’s wrongful competition, and that D stood to make $£ 200$ from that competition. C would release D from his obligation not to compete for $£ 101$ or more, since that would be more than she could herself make if she obtained an injunction (and ipso facto more than she would lose and could thus recover on the conventional basis). A rational $\mathrm{D}$ would buy the right to compete for $£ 199$ or less since that way he would make more than if $\mathrm{C}$ obtained an injunction and restrained him from competing. If both $\mathrm{C}$ and

\footnotetext{
${ }^{44}$ One Step (n 1).

${ }^{45}$ Cf the introductory sections of Gregory Klass, 'Efficient Breach' in Prince Saprai (ed), Philosophical Foundations of Contract Law (Oxford University Press 2014) for an excellent summary of the many ways in which classical economic reasoning in law and economics is based on a range of highly unlikely assumptions.
} 
D had perfect information, were rational and faced no transaction costs, $\mathrm{D}$ would buy the right to compete prior to competing for $\sim £ 150$.

Conversely, where competition decreases the overall profit available through eg a price war, $\mathrm{C}$ would not rationally want to bargain to release D from their non-compete. It is only where C's loss from D's competition is roughly equivalent to D's gain from that competition that the hypothetically negotiated release fee would be an accurate proxy for what the parties' might estimate C's loss to be. This is provided that the parties would have made any bargain at all in that situation since there is no financial advantage to either from the making of that bargain. However, at that point, it is uncertain why a court needs to go through the hassle of calculating what bargain the parties might have hypothetically arrived at, when that court could just have used the value the hypothetically constructed parties would have put on C's loss from competition.

If on the other hand, we assume plausibly that $\mathrm{C}$ would only enter a bargain where doing so would result in her receiving slightly more than she could receive from performance, the pretence that negotiating damages value loss is exposed to be just that - a pretence. It might be interjected, of course, that the parties might wish to come to an arrangement since that way they do not have to deal with the hassle of legal proceedings to either obtain an injunction or recover loss later on; however, once those transaction costs are taken into account, all other transaction costs ought to also be included ${ }^{46}$ If we ignore transaction costs for a moment and make the above assumption, negotiating damages create a sort of 'ratchet effect.' Once we recognise that negotiating damages are likely to overvalue C's loss, we must acknowledge that the availability of negotiating damages would allow $\mathrm{C}$ to capture some of the extra profit that

\footnotetext{
${ }^{46}$ C.f. e.g. the discussion in Gregory Klass, 'Efficient Breach' in Prince Saprai (ed), Philosophical Foundations of Contract Law (Oxford University Press 2014) 368-370, 375.
} 
$\mathrm{D}$ might be able to extract from the market in question. Of course, $\mathrm{C}$ can already do so to a certain extent through the availability of injunctive relief, the threat of which enables $\mathrm{C}$ to hold the more effective $\mathrm{D}$ to ransom should there be actual negotiations between the parties. However, it is seriously questionable whether such rent-seeking behaviours should be encouraged where $\mathrm{C}$ has not even attempted to obtain an injunction. To that extent, and in spite of the uncertainty created by Lord Reed's test, the decision is to be welcomed insofar as it reverses the wide availability of negotiating damages in contract cases. 